DOI: $10.4274 /$ tpa.46.52

\title{
Akne vulgaris; etyolojiden tedaviye
}

\section{Acne vulgaris; from etiology to treatment}

Ertuğrul H. Aydemir

Istanbul Üniversitesi Cerrahpaşa Tıp Fakültesi, Dermatoloji Anabilim Dalı, Istanbul, Türkiye

\section{Özet}

Akne vulgaris, pilosebase birimin enflamatuar bir hastalı̆ıdır. Hayati bir önemi olmamakla birlikte genç yaştaki hastalarda görünmesi ve beden imaj algılaması üzerindeki olumsuz etkileri nedeniyle çok önemli bir hastalıktır. Etyolojisi belli değildir, kalıtsal zemin üzerinde yağ bezi hipertrofisi ve işlevsel bozukluğu vardır. Artmış sebum salgısı, anormal foliküler keratinizasyon ve bakteri kolonizasyonu etyopatojenezi oluşturur. Tedavide yerel antibakteriyeller, yerel keratolitikler, sistemik antibakteriyeller kullanılabilir. Hormonların yeri çok sınırlıdır. Her üç etkene de etkili ve \%80 civarında kalıcı etki yapabilen sistemik isotretinoin ise akne tedavisinde bir devrimdir. (Türk Ped Arş 2011; 46 Özel Sayı: 132-4)

Anahtar sözcükler: Akne vulgaris, etyoloji, tedavi

\section{Summary}

Acne vulgaris is an inflammatory disease of the pilosebase unit. Although it is not a fatal disease, as it is seen in the young people and cause negative effects on body image perception its importance increase. Etiology is not clear, sebase gland hypertrophy and dysfunction is the genetical base. Hyperseborrhea, abnormal folliculaire keratinisation and bacterial colonisation are the elements of etiopathogenesis. Topical antibacterielles, keratolytics, systemic antibacterielles may be used. Hormones are limitedly used. Isotretinoine oral is a revolution in the treatment, with its permanent effect of $80 \%$ and efficiency on the all three factors. (Turk Arch Ped 2011; 46 Suppl: 132-4)

Key words: Acne Vulgaris, etiology, treatment

\section{Giriş}

Akne Vulgaris, üzerinde en çok konuşulan, en çok yorum yapılan dermatozlardan bir tanesidir. Türkçe olarak "Ergenlik Sivilcesi" diye anılır. Pilosebase birimin kronik iltihabi bir hastalığı olup, her iki cinste ve tüm ırklarda eşit oranda görülür (1-3). Genellikle ergenlik döneminde başlar fakat, bitiş zamanı değişkendir; 18-20 yaş olabileceği gibi 25-30 yaşlara kadar da uzayabilir ya da bazan daha geç yaşlarda başlaması da söz konusu olabilir (1-4). Genel sağlığı etkilemeyen, yaşamsal tehlikesi olmayan, basit bir hastalık gibi görünen "Akne vulgaris" insan iletişiminin üst düzeye ulaştığı günümüz toplumsal yaşamında yalnızca görüntüsü nedeniyle dahi çok büyük ve önemli bir sorun oluşturabilmektedir. Çünkü derimiz ve özellikle de yüzümüz, bu iletişimin bir numaralı görünen organıdır ve beden algılamasında en önemli yeri tutar. Ayrıca aknenin en çok görüldüğü yaşlar olan ergenlik çağı, beden algılamasının en yüksek olduğu, görüntünün bazı zamanlarda her şey olabildiği bir yaş dönemidir. Bu yaşlarda var olan lezyonun şiddeti on kat, yüz kat ya da daha fazla olarak algılanır ve gençlerde başta depresyon olmak üzere çok ciddi psikolojik sorunlara neden olabilir, tek bir papül dahi dünyanın kararmasına neden olabilir. Ayrıca uzun sürede kalıcı izlere de neden olabilen "Akne", işlevinin ve nesnel sorunlarının kat kat üzerinde önem taşır ve kesinlikle tedavi edilmesi gerekir.

Yazışma Adresi/Address for Correspondence: Dr. Ertuğrul H. Aydemir,

İstanbul Üniversitesi Cerrahpaşa Tıp Fakültesi, Dermatoloji Anabilim Dalı, İstanbul, Türkiye

Türk Pediatri Arşivi Dergisi, Galenos Yayınevi tarafindan basılmıștr. / Turkish Archives of Pediatrics, Published by Galenos Publishing. 
Aknenin etyolojisi çok tartışmalıdır. Kesin olan yanı yağ bezlerindeki büyüme ve aşıı çalışmadır ve bunların ortaya çıkması ise kişisel yatkınlığa yani kalıtsal özelliklere bağlıdır.

\section{Etyopatogenezde üç ana etken vardır}

a) Sebum yapımında artış

b) Anormal foliküler keratinizasyon

c) Mikrobik kolonizasyon (1-5).

Sebum miktarının artışının yanı sıra sebumun yapısı da değişiklikler gösterir ki aknenin temel patolojisi ya da diğer bir deyişle olmazsa olmazı sebum artışıdır. Sebumun artışı bakterilerin üremesine de uygun bir ortam hazırlayarak enflamatuar fazın oluşumuna dolaylı bir katkıda bulunur. Foliküllerdeki keratinize hücrelerin yapımında ve yapışkanlıklarında da bir değişiklik vardır ve bu yapışık hücrelerin sebumla birleşmesi sonucu aknenin temel elemanı olan komedonlar oluşur (2-4). Akne patojenezinde etkili olan, folikülde yerleşik asıl mikrorganizma Propionibacterium Acnes'tir. Staf. Aureus, P. Orbiculare ve seyrek olarak ta Demodex Follicularum vardır. Fakat bunlar enflamasyon sürecini etkilemez. Çoğalan P.Acnes'e karşı oluşan enflamasyon, aknenin papül ve püstül gibi enflamatuar elemanlarını oluşturur $(2,3,5)$.

Etyolojide androjenik hormonların kısmi etkileri dışında bilinen ciddi bir tetikleyici yoktur ki bunlar da yalnızca bayan hastaların sınırlı bir kısmında etkilidir (Özellikle polikistik over eşliğinde). Yiyeceklerin ve stresin etkisi çok tartışıımışsa da bu konuda da kesin bulgular gösterilememişti (1-3).

Akne, yağ bezlerinin fazla bulunduğu başta yüz olmak üzere sırt, göğüs ve omuzlarda yerleşir. Başlangıç lezyonları komedonlardır. Tipik olan ve tanınan komedonlarda folikül ağızları açık ve uçları siyah görünür. İri ve açık komedonlar çirkin olmakla birlikte, enflamasyon bunlarda değil, ucu açık ya da kapalı mikrokomedonlarda gelişmektedir. Eritemli papüller enflamasyonun ilk belirtileri olup, bunları püstüller izler. Seyrek olarak yağ bezlerinin çok irileştiği ve deri altında nodüllerin oluşumuna neden olduğu kistik akne tipleri görülür ki bunlar çirkin görünüşlü olduğu kadar tedaviye de dirençlidirler (1-5).

Akne tedavisinde en önemli şey hastayı ilgiyle dinleyip aydınlatmak, hastalık hakkında bilgilendirmek ve gerçekçi beklentiler oluşturarak hastanın tedavi uyumunun en üst düzeyde olmasını sağlamaktır. Tedaviler yavaş gelişimli olup, hastaya hedef olarak 6 aylık bir süre verilmeli, bu sürenin sonunda \%80-90 iyileşme olacağı, fakat tedavi bırakılınca yineleyebileceği, bu nedenle alt düzey bir tedavinin sürekliliğinin gerekli olduğu vurgulanmalıdır $(2,4,6,7)$.
Tedavinin en önemli kısmı yerel tedavidir. Yerel tedavi tek başına ya da sistemik tedaviyle birlikte kullanılabilir. Ayrıca idamede de tek başına yeterlidir. Yerel tedavi ajanları antibiyotikler, antiseptikler, komedolitik ve keratolitiklerdir (5-8).

Yerel antibiyotikler P. Acnes'in üremesini baskılayarak enflamasyon gelişimini önlerler, yalnızca antibiyotiklere direnç gelişmesi söz konusu olduğu için, başka antibiyotiklerle ya da antiseptiklerle dönüşümlü kullanılırlar. Ayrıca doğrudan antienflamatuar etkileri de vardır. Günde 1-2 kez uygulanabilir. Bunlardan en çok kullanılanlar eritromisin, klindamisin ve tetrasiklindir $(5,6,8)$.

Yerel antiseptikler de aynı şekilde etki ederler. Bunlarda direnç gelişimi yoktur ve etkilerinin antibiyotiklerinkine yakın olduğu bildirilmektedir. En çok kullanılanlar benzoyl peroksit, azelaik asit ve sodyum sulfasetamiddir. Aynı zamanda hafif komedolitik etkiye de sahiptirler $(2,4,6,7)$. Retinoidler aknede en çok kullanılan ilaçlardandır. Açık ve kapalı komedonları çok iyi etkileyerek, hem eskilerin atılmasını sağlar ve hem de yenilerin yapımını engellerler. Dolaylı olarak, $P$. Acnes üremesi de durur ve enflamasyon baskılanır. Antibiyotik ya da antiseptiklerle kombinasyonları çok iyi sonuç verir. İlk 20-30 günde tahrişe neden olurlar fakat daha sonra deri tolerans geliştirir ve tahriş azalır. Tretinoin ve adapalen bu grubun en çok kullanılanlarıdır $(6,7)$.

Sistemik tedavide antibiyotikler en sık kullanılanlardır. Eğer hormonal bir sorun varsa antiandrojenler sınırlı ölçüde devreye girebilir. Retinoidler ise giderek kullanımı artan özgün ilaçlardır $(2,4,7,8)$.

Sistemik antibiyotiklerden tetrasiklinler hem etkinlikleri ve hemde yan etkielrinin azlığıyla en çok yeğlenenlerdendir. Son zamanlarda doksisiklin daha öne geçmiş durumdadır. Trimetoprim ve eritromisin diğer çok kullanılan ve etkili olan ilaçlardır. Genelde 3-6 aya kadar kullanılabilirler ve sistemik antibiyotik kullanıldığında dierenç gelişimini önlemek için yerel antibiyotik kullanımı önerilmemektedir $(2,4,6,7)$.

Antiandrojenler daha çok polikistik overli bayan hastalarda kullanıır, fakat kullanımları sınırıdır (8).

Retinoidler, özellikle kistik akneler gibi sorunlu tiplerde çok kullanilırken, günümüzde inatçı ve psikolojik sorun yaratan orta şiddetli, klasik aknelerde de kullanılabilmektedirler. Sebum üretimini azaltır, etkin, enflamasyonlu yağ bezlerini etkisiz hale geçirir ve küçültür. Lipidlerin yapısını değiştirir. Sebum miktarını azaltı̆ı̆ı için de dolaylı olarak bakteri sayısını azaltır. Ayrıca keratinizasyonu da düzenleyerek, komedon gelişimini iki yönlü engeller. Doğru doz ve sürede kullanılırsa $\% 90$ oranında tekrarlamamak üzere kalıcı etki yapar. Buna karşlık, karaciğer enzimlerini, trigliseridleri ve kolesterolü arttırabilir. Depresyona eğilim, kemiklerde sorunlar gibi seyrek görülen diğer yan etkilerinin yanısıra en önemli yan etkisi 
gebelikte kullanıldı̆ında teratojenik etki yapmasıdır. Bu nedenle bayan hastalarda çok dikkatli olunmalıdır. Gerek retinoidler ve gerekse antiandrojenler kesin olarak dermatoloji uzmanı tarafından kullanılmalıdır (2,4,5-8).

Sonuç olarak "Akne", iyi bir yaklaşım, titiz ve sabırlı bir tedaviyle, hastayla iyi bir işbirliği yapılarak tedavi edilebilen önemli bir hastalıktır.

\section{Kaynaklar}

1. Aydemir EH. Akne Vulgaris etyopatojenez ve patolojisi. Adana: Çukurova Tıp Günlerii, 2002.
2. James WD, Berger T, Elston DM. Çev ed: Aydemir EH. Andrew's Deri Hastalıkları. İstanbul: Nobel Tıp Kitabevi, 2008:231-50.

3. Gülekon A. Akne etyopatojenezi. İstanbul: II. Vakıf Gureba Tıp Kongresi, 1995.

4. Cunliff WJ, Simpson NB. Disorders of the sebaceous glands. In: Champion RH, Burton Jl, Burns DA (eds). Textbook of Dermatology London: Blackwell Science, 1998: 1927-84.

5. Plewig G, Wolff HH. Braun Falco's Dermatology. Berlin: Springer 2000: 1053-82. (Full Text)

6. Aydemir EH. Aknede sistemik tedavi yaklaşımları. Ankara: 16. Prof.Dr. A. Lütfü Tat Simpozyumu, 2003.

7. Aydemir EH. Akne Vulgaris tedavisi. İstanbul: II. Vakıf Gureba TIP Kongresi, 1995.

8. Shaw JC. Hormonal therapy in dermatology. Dermatol Clin 2001; 19: 169-78. 